REVISTA de

PEDAGOGIE

\title{
A CRITICAL LOOK AT THE PORTFOLIO AS A TOOL FOR REFLECTIVE LEARNING: STUDENTS' PERCEPTIONS
}

O privire critică asupra portofoliului ca instrument pentru învăţarea reflectivă: percepţia studenţilor

\section{Elena MARIN}

Journal of Pedagogy, 2020 (1), 157 - 171

https://doi.org/10.26755/RevPed/2020.1/157

The online version of this article can be found at: http://revped.ise.ro/category/2020/

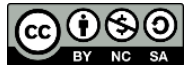

This work is licensed under the Creative Commons Attribution-NonCommercial-ShareAlike 4.0 International License. 94042, USA.

Published by:

Centrul Național de Politici și Evaluare în Educație UNITATEA DE CERCETARE ÎN EDUCAȚIE

http://www.ise.ro/

https://rocnee.eu/

Further information about Revista de Pedagogie - Journal of Pedagogy can be found at:

Editorial Policy: http://revped.ise.ro/editorial-policy/

Author Guidelines: http://revped.ise.ro/the-writer-guide-2/ 


\title{
A CRITICAL LOOK AT THE PORTFOLIO AS A TOOL FOR REFLECTIVE LEARNING: STUDENTS' PERCEPTION
}

Elena Marin*

\author{
University of Bucharest, \\ Faculty of Psychology and Educational Sciences, \\ Bucharest, Romania \\ elena.marin@fpse.unibuc.ro
}

\begin{abstract}
The new challenges faced by the future teachers make them assume a new role, that of reflective practitioner. Therefore, university programs should give future teachers the opportunity to engage in practical experiences that will stimulate their reflective skills and which can help create a strong and authentic teaching career. In this sense, a series of interventions, at a simulated level, were put into practice by the students in Pedagogy enrolled in year II at the University of Bucharest. After participating in the proposed activities, the students had to write a reflective essay. A series of focus-groups were organised in order to identify the students' opinion towards the use of a reflective essay as a way of professional training. The results show that the reflective essay is a tool that plays a significant role in building better and more meaningful learning experiences and helps in providing evidence-based methodological decisions.
\end{abstract}

Keywords: pre-service teachers, portfolio, reflective practice, university.

\section{Rezumat}

Noile provocări cu care se confruntă viitorii profesori îi determină să-şi asume un nou rol, acela de practician reflectiv. De aceea, programele universitare ar trebui să le ofere viitoarelor cadre didactice oportunitatea de a se implica în experien e practice, care le vor stimula abilită ile de reflec ie şi care pot ajuta la crearea

* Lecturer, PhD, Faculty of Psychology and Educational Sciences, University of Bucharest, Bucharest, Romania. 
unei cariere didactice autentice. In acest sens, o serie de interven ii, la nivel simulativ, au fost puse în practică de către studen ii înscrişi în anul II la programul de studiu Pedagogie de la Universitatea din Bucureşti. După participarea la activită ile propuse, studen ii au avut de redactat un eseu reflectiv. O serie de focus-grupuri au fost realizate cu scopul de a identifica atitudinile şi opiniile studen ilor/viitorilor profesori despre utilizarea unui eseu reflectiv ca o modalitate de formare profesională. Rezultatele arată că eseul reflectiv este un instrument care are un rol semnificativ în construirea unor experien e de învă are mai bune şi mai semnificative şi ajută la furnizarea de decizii metodologice bazate pe dovezi.

Cuvinte-cheie: portofoliu, practică reflectivă, universitate, viitori profesori.

\section{Introduction}

The international movement to reform teaching and improve the quality of education started by OECD (OECD, 1989) was based on the John Dewey's philosophy that emphasizes reflection as a deliberate and active process. As Dewey stated, reflection is an 'active, persistent and careful consideration of any belief or supposed form of knowledge and further conclusions to which it leads' (Dewey, 1933, p. 118). Reflection has been included in initial teacher training study programmes as part of a mandatory competency in many universities. In the new education paradigm, reflection is seen as an important aspect whose aim is to support the transition from a teacher training system that is based on competence towards a more professionally-oriented teacher training system.

This change is due to the new challenges that prospective teachers face and to the need to assume a new role calling for other skills than the subject matter (Eurydice, 2002). Particularly, these skills target the ability to critically reflect with an emphasis on the ability to link theory and practice and create and make use of specific strategies in order to deal with different and innovative learning situations, as well as develop an 'understanding of what they actually did know and also how the knowledge has been acquired' (Sultana, 2005, p.14).

Taking into consideration all these shifts that put a greater emphasis on the professional development of pre-service teachers rather than on their level of knowing and using information from their subject area, it seems natural to 
focus on developing a cognitive stimulating process based on the use of a reflective portfolio. The reflective portfolio is seen as a tool which would allow pre-service teachers to participate in critical reflection and lead to further learning. In this respect, Klenowski (2000) portrays reflective teachers as self-directed professionals that have the capacity to question, frame and resolve dilemmas of classroom practice, while Lyons regards the use of portfolios in assessment as a move towards a 'new professionalism' in teaching that has the potential to foster 'collaborative, interpretive communities of teacher learners who can interrogate critically their practice and uncover and make public what counts as effective teaching in today's complex world of schools and learners' (Lyons, 1998, p. 20).

\section{Reflective learning as a key concept in the teacher training programme}

Even though reflective learning is recognized by lots of professions to be an important tool for growth and development (Marzano, 2012), there is a lack of common vision regarding its value and its limitations in the literature. As presented in Dewey's work (1933), reflection provides the perfect background for discovery, argumentation, belief-disclosure, internalization of principles, all of these which are drawn from their learning experience. Moreover, Richards and Lockhart (1994) argue that reflective learning aims at examining the teaching experience as a source for change.

A constructivist view on the initial teacher training system, sees reflective practices and evidence-based training as an important asset for the $21^{\text {st }}$ century learners. However, reflection, regardless of its form, can produce change only if it is used in a systematic way, in a cyclical and spiraling process (Pollard, 2008).

As many educationalists agree, reflection is a process that is directly related to critical thinking, looking deep at an act or experience from the memory and trying to remember the details that can be connected to this particular event. Remembering the event and retrieving all the small details, just as a guided process, can facilitate the learning process to be more fruitful and more meaningful (Gough, 2007; Pollard, 2008; Richards \& Lockhart, 1994). 
Due to its multiple use, reflection can be considered vital in the teacher training programme. As Costa and Kallick (2000) state, reflection can support teacher learning through: promoting new understanding of their work through the insights of others; supporting teachers in making commitment to plans and innovations; documenting learning to provide a wide opportunity for shared knowledge. Several authors (Brockbank \& McGill, 2007; Henderson et al., 2004; Van Woerkom, 2010) concur that reflective practice strengthens values such as sustaining a better understanding or the process of deep learning; enables students to understand their own process of learning; helps students to development professionalism; helps put an emphasis on the process of constructing, deconstructing, and reconstructing knowledge based on rich learning experiences; ensure that the learning process is not restricted to formal settings only; helps create an authentic learning environment that is essential for deep learning (Iucu \& Marin, 2014).

\section{The importance of the reflective portfolio in the pre- service teacher training programme}

Yasin et al. (2012) show that the portfolio can also give evidence on the developmental process of each student. Zubizarreta (2004) sees the portfolio as a reflexive, evidence-based process that merged two important processes - the reflection and research process and, at the same time, emphasizes the importance of collaborative analysis of their own learning and their experiences that are related to a certain topic. More specifically, in preservice teacher education programmes, portfolios have multiple purposes starting with giving pre-service teachers the option to make up their personal philosophy regarding the teaching process (Hildebrand, 2005); also provides the chance to document his/her learning experiences (Loughran \& Corrigan, 1995); can boost pre-service teachers process of reflection on his/her individual strengths and weaknesses, leading to personal growth and development (Klenowski, 2000); encourages pre-service teachers to document and describe their skills and competence as teachers (Mosely, 2005); promotes student learning, professional development and reflection, as well as provides evidence for evaluation (Stone, 1998); and last but not least, it can be seen as a 'showcase' document that provides perspective on the teaching and learning achievements of the pre-service teachers and 
valuable insights for a prospective employer (Andrews et al., 2002). Berrill and Whalen (2007) see portfolios as a way to support a more focused reflection, instead of a vaguer thinking about internal learning experiences. Thus the portfolio becomes an important tool for empowering pre-service teachers to take control of their own learning process (Marin, 2015). As seen above, the advantages of using portfolio are wide, but McMullan et al. (2003) note that while the 'summative' aspect of the portfolio undermines student ownership, pre-service teachers did not give value to the portfolio unless they were going to get some credit for having completed it.

All in all, we can conclude that portfolios are a tool that students can use in order to develop reflective practice, especially in their pre-service teacher training; it provides pre-service teachers with a summative document outlining their achievements and a means to perceive themselves as future professionals (Chetcuti, 2007).

\section{Methodology}

\subsection{Methods}

The methodology used in this study consists of focus-groups developed at the end of the university course after pre-service teachers had gone through a full semester of teaching simulation. The focus-groups were organised yearly, for 4 years, when the course ended. The focus-group study aims:

- to identify the attitudes and beliefs of pre-service teachers with respect to the use of the reflective portfolio;

- to find out how relevant the reflective portfolio is for the pre-service teachers;

- to identify the pre-service teachers' autonomy during the process of reflection;

- to identify the benefits of using reflection activities in their future teaching career.

The focus-groups lasted approximately 60 minutes each. Then the transcribing and analyzing process began by using a coding system. The coding system is based on the theoretical framework developed during the literature review. 
In order to facilitate coding, the Maxqda 11 software was used so all the respondents' quotations were introduced and patterns were identified across different responses. The interviewers are identified by code, from I1 to I56.

\subsection{Participants}

A group of pre-service teachers $(n=56)$ representing students enrolled in their $2^{\text {nd }}$ year of study and finalizing their compulsory course (i.e., Classroom management) participated at these focus-groups. The structure of this course is based on a series of teaching activities that pre-service teachers must plan in groups, organize into the least details, put into practice and then evaluate their performance. Every teaching activity is based on the six dimensions of the classroom management as described by Iucu (2006): ergonomic, psychological, sociological, operational, normative and innovative classroom dimensions. Apart from planning a teaching activity, students have the task to write a reflective portfolio where they write their own reflection on the respective learning activity. On the one hand, we have pre-service teachers that prepare and implement a teaching activity and, on the other hand, we have pre-service teachers that observe their colleagues delivering a teaching activity. This provides pre-service teachers to a unique opportunity to develop a broader understanding of the process of teaching. The sample does not reflect the general population or appropriate population of students, but it is relevant for the institution in which this research was developed.

\section{Results}

5.1. Pre-service teachers' attitudes and beliefs about the reflective portfolio seen as a way to develop understanding through reflection

The aim of the reflective portfolio is to help students make connections to theories or to their own experiences while emphasizing their attention on how to use concepts related to the teaching and learning subject. While interviewing students on the relevance of portfolio as a way to acquire knowledge, three main aspects arose. The first one is related to the possibility of helping student to have a better understanding of what they really know 
and helping them to identify possible gaps. Also, another goal was to help students identify the benefits of the process of writing a reflective portfolio. First, students were faced with looking introspectively at what they know, what is the information they lack or the information that is somehow not deeply understood. One student agrees that:

'Being a process that spread through an entire semester there was a lot of time to start writing and putting into words the ideas that I had, related to the course, but somehow, mostly at the beginning of the course, I found myself not being able to express my ideas in the way that I wanted, and this was due to the fact that I lacked content and was not too familiar with the terminology.' (I23)

The process of writing a reflective portfolio is seen as an ongoing process that helps students to discover their gaps, with an emphasis on constructing a clear discourse. One interviewer agrees that:

'This inability to use terminology may show a lack of content mastery and furthermore can make the crucial difference between a professional in this field of classroom management and an amateur that expresses an opinion without having any theoretical background to sustain his/her arguments.' (I8)

Another aspect was related to pre-service teachers' autonomy in the learning process that is seen as the ability to keep a high level of motivation. In this respect, one interview stated that:

'The writing process of the reflective portfolio was overwhelming, I began with writing my beliefs which allowed me to express what teaching means for me, I don't think I had this opportunity before, and most importantly, it has encouraged me to continue with an innovative and energetic approach to improve and try to overcome my current teaching skills.' (I8)

Even though the process of improving our own teaching skills is mostly a personal one, the process of reflecting can have a boost from peer discussions. Also, it provides with a great opportunity to highlight some strengths and weaknesses that may interfere in teaching practices. Sustaining the ideas presented above, students stated that:

'This task went beyond just being a classroom task for which I would 
get a grade, for me it meant that I had to reflect on my personal beliefs and values, as well as my still <under the process> teaching skills [...] I strongly believe that reflective portfolios, though not an easy task, represent an essential tool that not only can help students to put in order and to give a clearer picture of what are their strengths and weaknesses when it comes not only to have a solid knowledge, but on the process of translating that knowledge into practice, when you start teaching. Also, I would like to bring into discussion the fact that the reflective portfolio can go beyond our university learning and can also be considered an important asset in the ongoing process of workplace learning and reflection on one's career.' (I32)

If the idea above is more thoroughly explored, it seems that there is a correlation between the process of reflection and the growth of the school community as a learning community. The school community, represented mainly by teachers, have to put pressure on the process of reflection on its own or as a group.

If the process of reflective thinking becomes a routine in the teaching career, it could be a step forward in the process of constantly improving teaching skills and also can be a useful tool to showcase the positive aspects and achievements of the teaching career that can increase job motivation, leading to the closing of the teacher gap as it is presented in the UNESCO report (UNESCO, 2016).

The third aspect brought into discussion during the focus-groups was the fact that the portfolio can be used in order to gather evidence that can help and support a better understanding of what it means to construct a fruitful teaching career in the $21^{\text {st }}$ century. Having a wide range of reflective portfolios that focus on different aspects of the teaching career can offer us the possibility to create a bank of experiences that teacher students go through and this can be seen as extremely useful in the process of updating and upgrading the teacher training programmes.

5.2. The level of autonomy of the pre-service teachers within the reflective process

The first aspect worth mentioning when talking about the pre-service teacher's 
autonomy level in handling the reflective process is the impact that the reflective portfolio has on promoting autonomous learning. In this respect, the process of sitting back and reflecting on the good practices that you can draw from the experience of observing someone's teaching or from evaluating your own teaching experience can have a great impact on the continuous professional development and growth as a professional in the educational field. One interviewee replied:

'The most important thing was realizing that my learning process depends mostly on myself and, because I am such a critical evaluator, I found out that sometimes I get stuck on going on and on through events that influenced my teaching [...] but overall it helped me consciously create my own educational philosophy.' (I13)

But too much autonomy during this process of professional development can have some negative impact on improving your teaching practices. For example, having too little direction from the coordinator may lead to a superficial reflection while writing a portfolio. Thus, the reflective portfolio will just simply be seen as a report, just as an interviewee observed:

'At the beginning, I wasn't used to thoroughly go through my learning process, so it was easier for me to just write the portfolio by describing that I did this and this and this [...] without having any valuable comments about what I really focused on, what worked and what did not, what students actually learn or what they will be able to do in the future based on what they have learned within this lesson.' (I34)

Moreover, having the autonomy to decide about the management of writing the reflective portfolio triggered some time management issues for these students. For them, the process of writing a reflective portfolio was somehow difficult due to the fact that they could not find the proper words to start writing and this information is supported by an interviewee who agrees that: 'The portfolio took many hours of preparation and searching, but mostly it took a lot of courage to start writing because I have the feeling that nothing special happened during the teaching process' (I51) or 'For me, the starting of the writing process was so painful because I would start writing, but after reading what I had written I immediately found it irrelevant and somehow feeling embarrassed 
of what I had written [...] maybe the presence of a tutor that asked for our pieces of writing to look over them and give us feedback more often could have helped me overcome this insecurity'. (I47)

5.3. Possible benefits from using this tool in future teaching career

The teaching career has and always will be an increasingly important aspect, as Europe constantly tries to address its educational, social and economic challenges. As pointed out in the Teaching Careers in Europe: Access, Progression and Support Report launched by the European Commission in 2018, teaching today focuses on lifelong career development, while adapting to new challenges, and collaborating with peers and does not forget the importance of using new technologies in the learning process. The teaching career is constantly changing and teachers 'need policy reforms in order to be able to respond proactively to the new requests' (European Commission, 2018). But in order to have strong and relevant policy reforms we have to deeply understand the dimensions of the teaching career. And what a better way to do this than by reflection. That is why we asked the participants of this study to think and evaluate the possible benefits that a reflective portfolio can bring in terms of their future teaching career. One of the main things which stands out is that this tool can help future teachers have a clearer and more objective perspective on their professional pathway:

'This tool enabled me to be very objective and to honestly think at the idea if this career is really for me, if I see myself doing this for the next 10 or more years on.' (I31)

Meanwhile, other respondents emphasized the experience of writing a reflective portfolio as a meaningful yet difficult process by:

'... critically evaluate myself as a future teacher but as I thought more about what works and what doesn't, for me as a teacher, I began to relax a little bit and allow myself to learn from my own mistakes; it was a hard period, of admitting that being good in one field does not necessary mean that you can teach that subject.' (I9)

Still, other interviewed students started this reflection journey from a positive perspective, showcasing the advantages and focusing on the process of 
learning and discovering the mysterious pathways into the teaching career: 'Reflecting back and forth was actually the most rewarding and helpful process because it enabled me to question what I was really doing, something that most teachers have insufficient time to do.' (I13)

Maybe one of the most important ideas that was identified by the interviewed students was the fact that it is not only important to reflect critically on personal and professional experiences, but also explore how these experiences can be translated into methodological decisions, further reflection that can be the activator of starting to build a community of practice amongst other teacher colleagues.

\section{Conclusions}

In this article we explored pre-service teachers' perspective regarding the importance of the process of writing a reflective portfolio. One main aspect that comes into light when talking about the use of a reflective portfolio is related to the opportunities that the students may have to identify their tacit knowledge and at the same time to identify the gaps in that knowledge, while being faced to look introspectively at what they know, what are the information they lack or the information that is somehow not deeply understood. Being able to reflect on your own level of understanding a subject can help you as a future teacher by supporting others to discover and better understand their own learning process. In other words, the results confirm previous studies that showed that being able to engage in a true and authentic reflection process can have an immediate impact on current and future classroom practices, sustaining the improvement of developing new practices (Russell, 1999).

Also, within this study, another relevant result focused on bringing into discussion the fact that the portfolio can be used in order to gather evidence that can help and support a better understanding of what it means to be a teacher-researcher, just as various researchers (Girod \& Pardales, 2001; Mills, 2000) revealed in their studies. Moreover, looking at the impact on the class and effects on the positive educational change that this practice of 
reflective portfolio use can bring, the results correlate with the findings that several authors declared in their studies (Mertler \& Charles, 2008; Wink, 2018) showing that having a critical perspective on your work does not only give you a clear image of your achievements, but it can also help you develop a better understanding of your learning process.

In terms of level of autonomy of the pre-service teachers that engaged in writing a reflective portfolio, it is believed that the process of sitting back and reflect on the good practices that you can draw from the experience of observing someone's teaching or from evaluating your own teaching experience can have a great impact on the continuous professional development. Other studies (Hariprasetya, 2017; Vangrieken, 2017) showed that the process of writing a reflective portfolio promotes growth as a professional in the educational field by enabling pre-service teacher's autonomy and collaborative attitude.

From a systematic point of view, the portfolio can be seen as a tool to gather evidence that can help and support a better understanding of what it means and what are the key elements which sustain the development of a fruitful teaching career in the $21^{\text {st }}$ century. Using the data that prove the importance of reflective portfolios, teacher training programmes can open the possibility to create a bank of experiences that teacher students go through and this can be seen as extremely useful in the process of updating and upgrading the existing teacher training programmes.

In conclusion, we strongly rely on the idea that it is not only important to critically reflect on personal and professional experiences, but also to explore how this experiences can be translated into methodological decisions, further reflection that can be the activator of starting to build a community of practice among the school community (Fry \& Venneman, 2018; Wang, 2018).

\section{References}

- Andrews, S., Ducharme, A., \& Cox, C. (2002). Development and use of electronic portfolios in preservice education. In Society for Information Technology \& Teacher Education International Conference (pp. 528-530). Association for 
the Advancement of Computing in Education (AACE).

- Berrill, D. P., \& Whalen, C. (2007). "Where are the children?” Personal integrity and reflective teaching portfolios. Teaching and Teacher Education, 23(6), 868884. https://doi.org/10.1016/j.tate.2007.02.002

- Brockbank, A., \& McGill, I. (2007). Facilitating Reflective Learning in Higher Education. McGraw Hill.

- Chetcuti, D. (2007). The use of portfolios as a reflective learning tool in initial teacher education: a Maltese case study. Reflective Practice: International and Multidisciplinary Perspectives, 8(1), 137-149.

http://dx.doi.org/10.1080/14623940601139111

- Costa, A. L., \& Kallick, B. (2000). Discovering and exploring habits of mind. Explorations in Teacher Education, 36.

- Dewey, J. (1933). How We Think: A Restatement of the relation of Reflective Thinking to the Educative Process. Henry Regnery Comp.

- European Commission/EACEA/Eurydice. (2018). Teaching Careers in Europe: Access, Progression and Support. Eurydice Report. Publications Office of the European Union. http://dx.doi.org/10.2797/309510

- Eurydice. (2002). The teaching profession in Europe: Profile trends and concerns: Report 1: Initial training and transition to working life. Eurydice.

- Fry, J., Klages, C., \& Venneman, S. (2018). Using a written journal technique to enhance inquiry-based reflection about teaching. Reading Improvement, 55(1), $39-48$.

- Girod, M., \& Pardales, M. (2002). Who am I becoming? Identity development in becoming a teacher-researcher [Paper presentation]. Annual Meeting of the American Educational Research Association 2001, Seattle, USA.

- Gough, D. (2007). Weight of Evidence: A Framework for the Appraisal of the Quality and Relevance of Evidence. In J. Furlong \& A. Oancea (Eds.), Applied and Practice-based Reasearch. Special Edition of Research Papers in Education, 22(2), 213-228. http://dx.doi.org/10.1080/02671520701296189

- Hariprasetya, A., Wiyono, B. B., Imron, A., \& Arifin, I. (2017). The relationship of academic supervision, educational profession insentive and teacher competence with teacher performance at the performing middle schools in Malange, East Java, Indonesia. Journal of Social Sciences (COES\&RJ-JSS), 5, 595-605.

- Henderson, K., Napan, K., \& Monteiro, S. (2004). Encouraging reflective learning: An online challenge. In R. Atkinson, C. McBeath, D. Jonas- Dwyer \& R. Philips (Eds.), Beyond the comfort zone: Proceedings of the 21 st ASCILITE Conference (pp. 357-364). Perth.

- Hildebrand, V. (2005). Returns to education in the European Union: a reassessment from comparative data. European journal of education, 40(1), 13-34.

- Iucu, R. (2006). Managementul clasei de elevi. Aplica ii pentru gestionarea situa iilor de criză educa ională ( $2^{\text {nd }}$ ed.). Polirom. 
- Iucu, R., \& Marin, E. (2014). Authentic Learning in Adult Education. ProcediaSocial and Behavioral Sciences, 142, 410-415.

- Klenowski, V. (2000). Portfolios: promoting teaching. Assessment in Education: Principles, Policy \& Practice, 7(2), 215-237. https://doi.org/10.1080/713613329

- Loughran, J., \& Corrigan, D. (1995). Teaching portfolios: A strategy for developing learning and teaching in preservice education. Teaching and teacher Education, 11(6), 565-577. https://doi.org/10.1016/0742-051X(95)00012-9

- Lyons, N. (1998). With portfolio in hand: validating the new teacher professionalism. Teacher College Press.

- Marin, E. (2015). Experiential Learning: Empowering Students to Take Control of Their Learning by Engaging Them in an Interactive Course Simulation Environment. Procedia-Social and Behavioral Sciences, 180, 854-859. http://dx.doi.org/10.1016/j.sbspro.2015.02.224

- Marzano, R. (Ed.). (2012). Becoming a Reflective Teacher. Marzano Research.

- McMullan, M., Endacott, R., Gray, M. A., Jasper, M., Miller, C. M., Scholes, J., \& Webb, C. (2003). Portfolios and assessment of competence: a review of the literature. Journal of Advanced Nursing, 41(3), 283-294. https://doi.org/10.1046/j.1365-2648.2003.02528.x

- Mertler, C. A., \& Charles, C. M. (2008). Introduction to education research $\left(6^{\text {th }}\right.$ ed.). Pearson.

- Mills, G. E. (2000). Action research: A guide for the teacher researcher. PrenticeHall, Inc.

- Mosely, C. (2005). The Value of Professional Teaching Portfolios to Prospective Employers: School Administrators' Views. Professional Educator, 27, 58-72.

- OECD. (1989). School and quality: an international report. Paris.

- Pollard, A. (Ed.). (2008). Reflective Practice: Evidence-informed Professional Practice. Continuum.

- Richards, J. C., \& Lockhart, C. (1994). Reflective Teaching in Second Language Classroom. University Press.

- Russell, T. (1999). The challenge of change in teaching and teacher education. In J. R. Baird (Ed.), Reflecting, teaching, learning. Perspectives on educational improvement (pp. 219-238). Hawker Brownlow Education.

- Stone, B. A. (1998). Problems, pitfalls, and benefits of portfolios. Teacher Education Quarterly, 21(1), 105-114.

- Sultana, R. G. (2005). The initial education of high school teachers: A critical review of major issues and trends. Studying Teacher Education, 1(2), 225-243. https://doi.org/10.1080/17425960500288390

- UNESCO. (2016). Education 2030: Towards inclusive and equitable quality education and lifelong learning for all (Incheon Declaration and Framework for Action). http://unesdoc.unesco.org/images/0024/002456/245656e.pdf.

- Van Woerkom, M. (2010). Critical Reflection as a Rationalistic Ideal. Adult 
Education Quarterly, 60(4), 339-356. http://dx.doi.org/10.1177/0741713609358446

- Vangrieken, K., Meredith, C., Packer, T., \& Kyndt, E. (2017). Teacher communities as a context for professional development: A systematic review. Teaching and teacher education, 61, 47-59. https://doi.org/10.1016/j.tate.2016.10.001

- Wang, L. (2018). On the Content of the Pre-service Teachers' Teaching Reflection in the Practicum. Theory and Practice in Language Studies, 8(9), 1195-1199. http://dx.doi.org/10.17507/tpls.0809.13

- Wink, D. J., Gane, B. D., Ko, M.-L., George, M., Zeller, L., Goldman, S. R., Pellegrino, J. W., \& Kang, R. (2018). Developing interdisciplinary competencies for science teaching and learning: A teacher-researcher professional learning community. Proceedings of International Conference of the Learning Sciences, ICLS, 3(2018), 1521-1522.

- Yasin, R. M., Rahman, S., \& Ahmad, A. R. (2012). Framework for reflective learning using portfolios in pre-service teacher training. Procedia-Social and Behavioral Sciences, 46, 3837-3841. http://dx.doi.org/10.1016/j.sbspro.2012.06.156

- Zubizarreta, J. (2004). The learning portfolio: Reflective practice for improving student learning. Anker.

The online version of this article can be found at: http://revped.ise.ro/category/2020-en/

\section{(oc) BY-NC-SA}

This work is licensed under the Creative Commons Attribution-NonCommercial-ShareAlike 4.0 International License.

To view a copy of this license, visit http://creativecommons.org/licenses/by-nc-sa/4.0/ or send a letter to Creative Commons, PO Box 1866, Mountain View, CA 94042, USA.
Versiunea online a acestui articol poate fi găsită la: http://revped.ise.ro/category/2020-ro/

\section{(cc) BY-NC-sh}

Această lucrare este licen iată sub Creative Commons Attribution-NonCommercial-ShareAlike 4.0 International License.

Pentru a vedea o copie a acestei licen e, vizita $i$ http://creativecommons.org/licenses/by-nc-sa/4.0/ sau trimite i o scrisoare către Creative Commons, PO Box 1866, Mountain View, CA 94042, SUA. 